\title{
A Study On Bharat Ratna Dr.M.G.Ramachandran's Philosophical Film Songs With Special Reference to the Socialistic And Communistic Ideas It Contains - An Academic Comparative Analysis with the Theory of Socialism as Propounded by Karl Marx
}

\author{
P. Sarvaharana ${ }^{1, *}$, P. Thiyagarajan ${ }^{2} \&$ S. Manikandan ${ }^{3}$ \\ ${ }^{1}$ School of Contn. Edn., Department of Economics, Tamil Nadu Open University, Chennai, India. \\ ${ }^{2}$ Dept. of Philosophy, A.M. Jain College, Meenambakkam, Chennai, India. \\ *Correspondence: Indian Institute of Technology, Madras, Chennai-600036, Tamil Nadu, India. Tel: \\ 91-944-424-7688. E-mail: sankarsarva@iitm.ac.in
}

Received: June 20, 2017 Accepted: September 10, 2017 Online Published: December 15, 2017

doi:10.5430/wjss.v5n1p46 URL: https://doi.org/10.5430/wjss.v5n1p46

\begin{abstract}
Providing quality songs in movies has become paramount importance on the part of film Producers and Directors. Of late the heroes of the movies are also concerned about the contents of the song; as they play the main role in the movies and are watched by millions of fans. Super-hero who attained matinée idol status like Makkal Thilagam Bharat Ratna Dr.M.G.Ramachandran took upon himself the responsibility of not only producing quality movies but also paid personal attention to produce quality songs as he thought that good messages can be disseminated through his film songs to millions of his fans. It is due to this fact Bharat Ratna Dr.M.G.Ramachandran sought the assistance of eminent lyric-writers like the great Kannadasan, Valli, Marudhakasi, Udumalai Narayana Kavi and also encouraged other emerging writers like Na Muthulingam to write songs for his movies. In view of such extraordinary efforts made by Puratchi Thalaivar Dr.MG Ramachandran, his film songs contain ideas of ethics, education, equity and justice (communism), eradication of corruptive practice. In this paper an attempt has been made to deal with Twelve of such songs that contain SOCIALISTIC AND COMMUNISTIC IDEAS and a comparative analysis has been made with the Socialistic and Communistic theory as propounded by the Great Karl Marx. This paper consist of:- Need of the Present Study; Scenario of Cinema; Scenario in Tamil Film Industry; A Bird's Eye View of Dr.M.G.Ramachandran's life history. After introducing Karl Marx, the theories propounded by him such as the Alienation and Materialism are discussed; thereafter the Grounds for Comparison has been arrived; then the efforts taken by Dr.MG.Ramachandran to produce quality songs has been discussed. Finally a Comparative Analysis of the twelve songs identified that contain the ideas of Socialism and Communism has been discussed in detail.
\end{abstract}

Keywords: Bharat Ratna Dr. M .G. Ramachandran, Karl Marx, context, critical analysis, communist manifesto, Alienation

\section{Introduction}

The technological advancement made over the still camera had paved the way for movie camera. With the technology of movie camera, technicians tried to capture moving objects. Initially they video graphed less than a minute of action in 1890's. Using this technology, silent pictures were produced for three decades. It was in 1927 the first speaking movie "The Jazz Singer" was produced by Warner's Brothers that had opened up avenues for exploration in the annals of history of media industry to produce movies of astounding nature. This media industry is now grown to the extent of live telecast of events and video-conferencing. There is no stopping to such advancement in the era of information exploration which may perhaps go beyond anyone's imagination. Music according to the scene, theme and action of the characters in a movie is essential for a live experience to the audience. Songs according to the story and nature of the character had become inevitable for production of a movie. A combination of all these would give better result and gratify the curiosity of the audience. Providing quality song in the movies 
always engaged the attention of the producers and directors. Beyond these two important functionaries in production of movie is the production of quality song with meaningful lyrics. The heroes of the movies also concerned about the contents of the song; as they play the part in the movies which would be viewed by millions of their fans. Super-heroes who attained matinée idol status like Makkal Thilagam MGR took upon himself to produce not only quality movies but also paid personal attention to produce quality songs as he thought that good messages can be disseminated through songs and thereby millions of his fans will get the message and the society as well (Sarvaharana, Thiyagarajan \& Manikandan 2017). It is due to this fact Bharat Ratna Dr.M.G Ramachandran sought the assistance of eminent lyric writers like the great Kannadasan, Valli, Marudhakasi, Udumalai Narayana Kavi and also encouraged other emerging writers like Na Muthulingam to write lyrics for his films. In view of the efforts made by Puratchi Thalaivar Dr.MG Ramachandran, his films contain songs with philosophical import. Especially one can witness ideas of ethics, education, equity and justice (communism), eradication of corruptive practice etc. appears in his film songs. Even the songs of love and romance of his movies coincide with Tamil Tradition and Culture. In this paper an attempt has been made to deal with several of his film songs that coincide with the theory of Socialism and Communism as propounded by Karl Marx. A new methodology by way of "Context" has been evolved to arrive at the theoretical comparison. Each "Context" will contain - translation of the song in English; interpretation of the sum and substance of the song and in the end of each context a Critical Analysis has been made to clearly denote the theoretical genesis of the subject matter. The Organization of this Research Work has been presented in the following manner:

1. Need of the Present Study

2. The Scenario of Cinema

3. Songs and Music Ruled the Roost

4. Scenario in Tamil Film Industry

5. Bird's Eye View of Dr.M.G.Ramachandran's life history

6.1.Introduction of Karl Marx; 6.2. Marx's greatest finding "the Alienation"

\subsection{Materialism; 6.4. Grounds for Comparison}

7. Dr.MG.Ramachandran produced quality songs by availing the services of eminent

Tamil scholars (writers) for the benefit of the society.

8. Comparative Analysis of the Twelve songs identified with the above ideas that contain

the ideas of Socialism and Communism as propagated by Karl Marx .

\section{The need for the Present Study}

It is reported that Movies and music have been a natural combination ever since sound was first added to moving images. Whether a film is a tear-jerking drama, an action-packed thriller or a side-splitting comedy, the right song at the right moment will always elevate the impact of a scene. Not only that, many songs written for films have stood on their own, with the popularity of some eclipsing the movies that inspired them. However, there were bewildering outcomes that were reported in research studies about emotional impacts created by music's and their adverse effects particularly on the youth. The American Academy of Paediatrics reports adverse and staggering impact created by rap music that panics the listener and goes to the extent of altering their character and they go wild and commit mistakes resulting into crimes (American Academy of Pediatrics 2010). Taking reference from research findings of Roberts F, St.Lawrance JS.Joynes in their research papers such as Popular music in Childhood and Adolescence and the effects of sexually violent rock music on males acceptance of violence against women respectively; this report which has been published with a view to guide and define the Child Health Care System and / or Improve the Health of all Children. This report expresses concern over heavy metal music listening that result in increased depression, delinquency risk behaviour, smoking and conduct problem. This report exclaims that fans of heavy metal and rap music showed a greater tendency to engage in reckless behaviour than their peers who were not fans of this type of music. It is here the present study is important that the identified songs propagate the ideas of socialism and communism (equity and justice in society) to the masses and establish the fact that celebrities who had huge fan followers has the responsibility to guide them to be responsible citizens in the society. It is not an over statement to mention here that Dr.MGR had taken up on himself this great responsibility with determination without any fear on the success of his movies. In response to the felicitation function organized by 
the film industry to honour him on the eve of receiving the award of degree of doctor (honoris causa) Dr.M.G.R appealed to Bakiyaraj (film director and producer), Bharathi Raja (film director and producer) Rajinikanth and Kamalahasan (famous actors who has huge fan followers) in the following manner:

For your life and profession you have entered in to this field; however, see that you can propagate message through your story and songs to integrate the nation and the people. If you do so, not alone MGR or Shivaji; though we have done something but you can do wonders with the latest advancement in the technology. While using the latest technology your ability will also grow; using this do something good to the society. You may live 100 years or 150 years, in the end what you have done to the welfare of the society that counts. You should not receive censure from the future generations (Kumaravel. Ve. 2015).

\section{The Scenario of Cinema}

It was in 1927 the first speaking movie produced by Warner's Brothers titled "Jazz Singer" released in America. Later, in 1931 a film by name "Alam Aara" was released in India. That was the first movie from Indian Cinema Industry which was produced in Hindi and Urudu. The person who produced the movie Alam Aara also produced "Kalidas" in Tamil and Telegu. During those days there used to be more than 50 songs in a film and Kalidas itself consisted 50 songs. Though the movie Kalidas was produced at the expense of Rs.8000/- it fetched an overwhelming collection of Rs.80,000/-(Idaya SJ, 2016). It is a fact that when cinema came in to existence in India, movies were produced on the basis of stories from puranas (Ramayana, Mahabharatha and other philosophical and mythological stories) because the general masses wanted to see their heroes such as Sri Rama, Lord Krishna and others in movies as they have heard them only from the holy books. Kalidas was a famous story from Sanskrit. Later, producers tried to produce films dubbing from other languages including other countries. For example, the movie "Man in the Iron Mask" was produced in Hollywood based on a novel. Mr. Sundaram of Modern Theatres produced a movie called "Uttama Puthiran" dubbing from Man in Iron Mask (Idaya SJ 2016). When the Indian film industry was producing movies on the basis of stories from the puranas (Puranas are a class of literary texts, all written in Sanskrit verse. The word "Purana" means "old", and generally they are considered as coming in the chronological aftermath of the epics) and popular kings of ancient past; few movies on social movements such as Menaka, Anathai Pen and Sabapathi were produced. However, when the movie by name Nam Iruvar (we two) released in 1947 by AVM Productions; many movies on the basis of social evils or crisis were produced. AVM productions flourished in the Tamil Cinema enduring restrictions from the Government of India owing to Second World War. It should be emphasized here that the screen play written by Peraringer Anna for movies such as Velaikkari (Servant Maid) or OrIravu (one night) on the basis of social evils attained great success and Anna became popular during 1940's. The greatest success that was achieved by the Tamil Film Industry was the production of the film "Para Sakthi" screen play written by Dr. Kalaignar Karunanithi (a great political leader known for his scholarship in Tamil and former Chief Minister of Tamil Nadu many times) which had attracted the attention of many people in Tamil Nadu.

\section{Songs and Music Ruled the Roost}

History of world cinema proclaims that certain movies became popular because of its super-hit songs. For example, Broadway melody was a super hit movie in the 1930's which hit the box office at US\$ 3.00 million, and music and its lyrics attracted the attention of millions of fans (The Broadway Melody -Wikipedia). In collaboration with Arthur Freed, who wrote the lyrics, Mr. Brown compiled an impressive list of standards, such as, "You Were Meant for Me," "You're an Old Smoothie," "BroadwayMelody of 1929," "All I Do Is Dream of You" and "Alone". Again the film The Great Ziegfeld released in 1935 amazed the world of cinema by its scintillating songs (The Great Ziegfled - Wikipedia). In 1944 Going My Way composed by Robert had certainly dominated the Hollywood. A biggest comedy but infused music in the movie and become highest grasping movie that had hit the box office of the value of 7.5 million; that had made even the Pope to admire and offered accolades. This movie had won seven Oscar Awards in all the categories. One of the biggest successes in film in the 1930s and the pride of MGM at the time, it was acclaimed as the greatest musical biography to be made in Hollywood and still remains a standard in musical film making. Again in 1951, An American in Paris known for its success towards music (Steve Sullivan 2017). In 1960's Leyoned Bird - West Side Story won Oscar in all the categories including the best music and best song; more to say that more innovation has been made in sound mixing in the movie and stood as the first and foremost in the innovation of sound mixing and paved the way for more exploration in the future not only in the Hollywood film industry but also in other film industry as well. Released on October 18, 1961 through United Artists, the film received high praise from critics and viewers, and became the second highest grossing film of the year in theUnited 
States. The film was nominated for 11 Academy Awards and won 10, including bestpicture (as well as a special award for Robbins), becoming the record holder for the most winsfor a movie musical (The West Side Story Wikipedia).

\section{Scenario in Tamil Film Industry}

The fact remains the same in Tamil Nadu, Southern India wherein there were films which had become popular for its songs as they contained lyrics with full of meaning. Consider the following wonderful song from the movie Kalaigarai Vilakkam (1965) Written by Pavendar Bharathidasan; Sung by Mrs. P. Suseela and Seergazhi Govindarajan; Music by M. S. Viswanathan.

Blow Oh conch! blow Oh conch! Blow Oh Conch

Exclaim that our life and welfare depends on the effervescing Tamil (language)

Our enemies had vanished on seeing the Tamils united here

To pester trouble to the gorgeous Tamils' destruction alone would be imminent

Just blow this news oh Conch that our mother tongue

Tamil had taken birth with the rising (red like)

Sun along with the sky and the resounding ocean

Just blow oh Conch to make the inferior folk aware

That we Tamils belong to the lion hearted sect

Though we suffer due to poverty but exclaim oh conch that

Our shoulders are the shoulders that attain only victory

Our mind is similar to the holy river Ganges - from it springs only noble thoughts

Our breath itself had smelled the blood-shed of victory on the battle-field

\section{Interpretation}

Pavender Bharathidasan wonderfully drives home the affinity the Tamil people have towards their language. Indeed Tamil language has a perpetual co-existence of cultural heritage that propagate the idea of righteous living with the ultimate aim of attainment of immortal bliss and thereby the Tamil Culture became a beacon to mankind. This song also proclaims the importance of unity among the Tamils, the quality of fearlessness that is believed to be part of every Tamil folk who give importance to bravery.

\section{Brief History of Dr.MGR (A bird's Eye View)}

Dr.MGR belonged to a majestic family. His father Shri.Maruthur Gopalan was a district magistrate in Thrishoor of Kerala. Shri. Maruthur Gopalan was so straight forward and gave verdict against his own relatives on the basis of merit of the case. This had resulted in rift within the family circle and Maruthur Gopalan decided to move to Srilanka in 1913. Ramu Pillai and Velupillai supported MGR's father financially to settle in Kandi of Srilanka (Shrikanth Veeravalli 2013). Marudur Gopalan was initially employed as an English teacher in a College and later entered in to the judiciary service of Sri Lanka as a District Judge of Kandi (Ramakrishnan.K.P. 2007). Dr.MGR was born on 17th Jan. 1917 at Kandi of Srilanka. Sri.Muruthur Goplan, passed away in 1920 at that time MGR's age was only three. After the demise of Shri.Maruthur Gopalan mother Satyabhama moved to Kumbakonam of Tamil Nadu where Mr. Narayanan lived. Mr. Narayanan was the maternal uncle of Dr.MGR. Dr.MGR and his elder brother Sri.Chakrapani studied in a Government school in Kumbakonan. Due to compelling situation prevailed in the family, MGR decided to take up employment at the very young age and joined Madurai Original Boys Company with the help of his uncle Mr. Narayanan. Mother Satyabhama agreed to this idea with great hesitation. Initially MGR's salary was four and half rupees per week. In this company MGR associated with comedy actor Kali; N. Ratinam and PU Chinnappa. MGR learnt the nuances of acting and acted more than 30 dramas within the age of 15 years. MGR along with his brother MG Chakrapani got a chance to act in the movie "Sathi Leelavathi". MGR's role in the movie was "Inspector". The movie was released in the year 1936 and both of them received a salary of Rs.100/-. First time MGR could own a hundred rupee note. In course of time, many chances to act as inspector in various other movies 
came but MGR did not accept as he feared that he will be sealed in the role of an inspector for ever.

However, he acted in small roles in movies like Iru-Sagothirargal (two brothers), Maya Machindra, Prahaladan, Ashokumar, Sitha Jananam, Tamilarium Perumal, Dasipen that proved his acting skills. Later he was offered a chance to act as a hero in the movie "Chaya" but production of the movie was later dropped. Thus for nearly nine years MGR had to struggle before he actually got a chance to act as an hero in the film Rajakumari released by Jupiter Pictures. Rajakumari was released in 1947 and, much to the surprise of Mohideen, it turned out to be a big success! The profits were huge. MGR arrived as a hero and it was the beginning of an astonishingly successful career that would be discussed for years to come exclaimed in the leading English News Paper (The Hindu, 1947). Later, A.S.A. Samy's Marmayogi (Robin Hood like adventure) set the formula for MGR films where he bashed up the villains and saves the heroine. The trend of the solo entry song for the hero started with MGR in his film Malai Kallan, where he appears singing 'Ethanai kaalam thaan aemaatruvar indha naatiley' (How long did politicians try to cheat people). The period witnessed, so to say the transformation of a matinee idol becoming a demi-God for his fans and MGR joined the political party, Dravida Munnetra Kalagam (DMK) in 1953 owing to the influence of C.N. Annadurai (Ram Pande, 1985). Jupiter Films, a significant film production company from Coimbatore that made path-breaking films such as Menaka and Velaikkari that dealt with social issues such as widow re-marriage and women empowerment. "They set new trends at a time when mythological films ruled. They replaced songs (sometimes going up to a 100 in one film) with dialogues in chaste Tamil, and reached the common man. Velaikkari is adapted C.N. Annadurai's play. It marked Arignar Anna's debut in films as a writer and it is such films that later played a role in strengthening the Dravidian political movement," The film created the trend of the concept of "Robin Hood" and inspired various films like Neelamalai Thirudan (1957), Malaiyoor Mambattiyan (1983), Gentleman (1993) and Sivaji (2007) The film Malaikallan also created the trend of philosophical songs and introduction songs for the lead actors (The Hindu, MARCH 20, 2014) own the National Film Award for Best Feature Film in Tamil President's Silver Medal in 1954 at the 2nd National Film Award ( Ministry of Information, Government of India, 1955).

The dream of common man in Tamil Nadu that their Hero should become a political leader and rule them had come true when MGR founded AIADMK in 1972 and then became the Chief Minister of Tamil Nadu in 1977. Some of the major welfare schemes that were introduced by him as Chief Minister of Tamil Nadu are:

- He ordered $20 \mathrm{~kg}$ of rice to be given through Public Distribution System through TUCS and reduced the rate of rice to Rs.1.75/-

- He introduced scheme for assistance to the destitute women for their marriage expenses.

- In 1980s MGR took strict action against Naxalites. He gave free hand for the police to go against the naxals and till today there is no naxalism/maoism in Tamil Nadu.

- M.G.R implemented lot of freebies to whom it is really needed. Freebies including Sewing machine for ladies etc.

- M.G.R opened Vandalur Zoo, the largest zoological garden in India.

- M.G.R created Tamil University in Thanjavur.

- M.G.R conducted 5th Tamil World Conference in Madurai.

- M.G.R established nearly six Universities Mother Therasa Women's University

- Bharathiar, Bharathidasan and paved the way for establishing private engineering

- colleges realizing the importance of creating technical manpower.

- He was successful in getting share of Cauvery Water from Karnataka with his personal visit to the then Chief Minister's residence.

- Introduced the famous free mid-day meals scheme called the Chief Minister's Noon Meals Scheme.

\section{Introduction of Karl Marx}

Karl Marx (1818-1883) was a German philosopher, political economist, historian, political theorist, sociologist, communist, and revolutionary, whose ideas played a significant role in the development of modern communism. Marx in the Communist Manifesto that was published in 1848 exclaimed that "The history of all hitherto existing society is the history of class struggles." Marx argued that capitalism, like previous socio-economic systems, would inevitably 
produce internal tensions which would lead to its destruction. Just as capitalism replaced feudalism, Marx believed socialism would, in its turn, replace capitalism, and lead to a stateless, classless society called Pure Communism. In this pure communism Marx expects men would live a life of equality. Marx denotes that the condition precedence for foremost historical act is the production of material life itself and when the needs relating to food clothing and shelter are fulfilled by means of gratification man tries to create new needs and there is no end to such needs and gratification as he denotes men as a "perpetually dissatisfied animal" (Karl Marx 1964). History of the world reveals that the members of the aristocracy and the church had owned the means of production, and the peasants worked for the aristocracy. With the onset of the Industrial Revolution, Marx thought that the working poor will rise financially and socially. However, this did not happen and to his dismay aristocracy was replaced by the capitalists and Marx calls them Bourgeoisie. The working class who were once peasants were replaced as wage earners under the capitalist and Marx calls them as Proletariat. Marx believed that capitalism which is inherently unfair, since workers under this system were becoming poorer and poorer and were alienated. And in this vicious circle of Alienation the workers are becoming distanced or isolated or both from their work, resulting not only a feeling of despondency but they have certainly become powerless and thereby could not feel free to develop their skills and go beyond the pale of the shackles of bondage as industrial workers!

\subsection{Marx's Greatest Finding "the Alienation"}

Imagine a capitalist society that consist of majority of labourers who are powerless and suffer from despondency and they are artificially made to depend on the business men who assumed feudal power in the society. To alleviate this alienation Marx propounded an unequivocal theory and wanted capitalism to be replaced by a socialist system that will make people equal and thereby their needs met. What is the meaning of alienation and how does Marx defines is the explained here under:

Lewis A. Coser hails that according to Marx Alienation may be described as a condition in which men are dominated by forces of their own creation, which confront them as alien powers. The notion is central to all of Marx's earlier philosophical writings and still informs his later work, although no longer as a philosophical issue but as a social phenomenon (Lewis A. Coser).

Marx asked:-In what circumstances do men project their own powers, their own values, upon objects that escape their control? What are the social causes of this phenomenon?

Marx is of the view that all major institutional spheres in capitalist society, such as religion, the state, and political economy, were marked by a condition of alienation and that the various aspects of alienation were interdependent and came to a conclusion that Objectification is the practice of alienation. Just as man, so long as he is engrossed in religion, can only objectify his essence by an alien and fantastic being; so under the sway of egoistic need, he can only affirm himself and produce objects in practice by subordinating his products and his own activity to the domination of an alien entity, and by attributing to them the significance of an alien entity, namely money. Therefore it is the state's responsibility to guarantee its citizens the fundamental freedom and regard each individual as equal whether he is rich or poor. Such a state that assures such a liberty is truly democratic.

\subsection{Materialism}

Delinking the morality and moral and spiritual uplifitment of a person (perhaps Marx leaves to the consciousness of the individual) studied the relationship and importance of money in man's material life. Here Marx's opines that money is the alienated essence of man's work and existence; the essence dominates him and he worships it. It is not an exaggeration when we say, money has enslaved men due to the intrinsic and imperative physical needs and it is difficult to imagine the monotonous material life of human being without money and that is the reason why Marx called man's material life as the economic life and in this economic life majority of them are made to work as industrial labour to earn for their livelihood. They are oppressed by the capitalists (industrialist) who are few in percentage when compared to industrial workers and try to dominate them in all spears of life i.e. economic, political and social and Marx concludes that the alienated industrial worker's freedom of choice has been freezed by the Industrialists. He re-emphasizes that "the state is the intermediary between men and human liberty" just as Christ is the intermediary to whom man attributes all his own divinity and all his religious bonds, so the state is the intermediary to which man confides all his non-divinity and all his human freedom and therefore the state is duty bond to create an atmosphere wherein everyone is equal. Karl Marx says that "as the contradictions of capitalism become greater, more intense, and less amenable to disguise, neither the state nor ideology can restrain the mass of the workers, white and blue collar, from recognizing their interests (becoming "class conscious") and acting upon them. The overthrow of capitalism, when it comes, Marx believed, would proceed as quickly and democratically as the nature of capitalist opposition allowed. Out of the revolution would emerge a socialist society which would fully utilize 
and develop much further the productive potential inherited from capitalism. Through democratic planning, production would now be directed to serving social needs instead of maximizing private profit. It should be understood that maximum social benefit would be attained only by serving the social needs of the majority and maximising private profit would create a huge gap between haves and have nots. The final goal, toward which socialist society would constantly build, is the human one of abolishing alienation. Marx called the attainment of this goal "communism" (Bertell Ollman).

\subsection{Grounds for Comparison}

Communism, which is also described as "Revolutionary Proletarian Socialism" or "Marxism," is both a political and economic philosophy. The abridgment of Communism is enclosed in two primary writings: (Lewis A. Coser) The Communist Manifesto, which was first published in 1848 by Karl Marx, and (V.1. Lenin,) Principles of Communism, by Friedrich Engels. At the request of the Communist League, an activist group they were members of, Marx and Engels together authored The Communist Manifesto. The main goal of The Communist Manifesto was to focus on class struggle and motivate the common people to riot. Even more so, it was designed to envision a model government, whose economics would destroy the upper class - freeing the lower class from tyranny. According to The Communist Manifesto, Communism has ten essential planks and they are:

- Abolition of Private Property.

- Heavy Progressive Income Tax.

- Abolition of Rights of Inheritance.

- Confiscation of Property Rights.

- Central Bank.

- Government Ownership of Communication and Transportation.

- Government Ownership of Factories and Agriculture.

- Government Control of Labor.

- Corporate Farms and Regional Planning.

- Government Control of Education.

Fundamentally, The Communist Manifesto was a rebellion against the extreme poverty of the lower class and aimed to bring in alleviation through struggle and the objective and scope of the paper is to find out whether Dr.MGR's film songs contain these thoughts. Dr.MGR had acted in 136 films and they contain as many as 600 film songs wherein those songs which contain these thoughts especially labour welfare ideas were identified and due to limitation of the paper only 13songs were selected and they are discussed one by one as under:

It has been decided to earmark each song which is appropriate to the above idea as each context and thereby each context will contain the translation of the song in English, the interpretation of the song and finally critical analysis with reference to the identified context will also be given so that the theoretical comparison with the particular context is established or arrived at. Before discussion of each context the following justification has been provided to establish the fact that Dr.MG.Ramahandran scans through each song written for his film.

9. Dr. M G. Ramachandran Produced Quality Songs by Availing the Services of Eminent Tamil Scholars (Writers) for the Benefit of the Society

The weekly Tamil Magazine "KUMUDAM" brings out articles in the heading "Ayirathil Oruvan" in memory of Bharat Ratna Dr.MGR's centenary celebrations. Under this chapter, celebrities who had associated with Dr.MGR were requested to share their experiences with him. Kavinger (Poet) Na Muthulingam shared the experience he had with Dr.MGR. It is stated here that Na Muthulingam had written more than 1500 film songs and a popular lyricist. Muthulingam writes "like Purachithalaivar (i.e. Revolutionary Leader) Dr.MGR, his songs are also immortal". It is Dr.MGR who gave importance to aesthetics to tunes and construction of new and meaningful words in the songs and therefore Dr.MGR songs stands tall; generation after generation (Muthulingam.Na 2007). He further writes that it was very difficult to get MGR's concurrence and finalize a song. Some songs were accepted by him in a single day. At the same time, it took moths to get the songs accepted by MGR. For example Muthulingam states that he wrote three songs for MGR's movie "Madhuraiyai Meeta Sundara Pandian" and it took months to get MGR's consent to 
finalize the song. Again in his essay (chapter) in the book (Sabitha Joseph 2014) Na Muthulingam reiterates that: MGR wanted to introduce good ideas in music in his film songs so that it will get in to the minds of his fans and that is why he paid enormous attention to it. Soon after MGR become the Chief Minister of Tamil Nadu the daily Washington Post exclaimed that it was because of the popularity MGR gained through his philosophical songs he was able to snatch such a victory (Muthulingam.Na. 2014). Muthulingam further states that MGR used to advise him in the following manner (in the words of MGR):

"Even when you write songs relating to sad news for the movies you should not use half words". When Pattukottaiar writes sometimes half-words would come (that will make the concept in complete) however, it will not happen to Kannadasan. Mix Pattukottai and Kannadasan in your writings'.

Muthulingam states that for the movie "Indrupol Endrum Valka" the original first song was different and what was taken place was different. The first song was "pathai mari ponavare payanam yenge sollunga" (i.e. deviated from your chosen path where is your journey). Director Sridhar told that the meaning of this song will coincide with the situation in the story. But MGR advised do not to write incomplete concepts as our ideology is undisputed. After this alone, I wrote the super-hit song Anbukku Nan Adimai, Tamil Panbukku Nan Adimai - (I am slave to eternal love and I am slave to the ethical values of Tamil Language). The above enlightens the fact that Dr.MGR wanted the lyric writers to write songs in accordance with his ideas and these ideas mainly centred on the rights of the poor's, their upliftment, social inequalities and the need for decentralization of wealth; weeding out of corruptive practice and inculcating moral values in the society. It is therefore, not a mere exaggeration to state that Dr.MGR knows the lyrics of a song including its meaning and the purpose for which it was written for his movie. In other words, Dr.MGR wanted the lyric writers to compose songs according to his ideology. To substantiate the above facts the following is quoted:

After the great success of his movie Nadodi Mannan (Vagabond King) Dr.MGR shared his views on the story selection and various other aspects of producing the movie including lyrics of the songs (Kumaravel.Ve 2015):

In the words of MGR:

The lyrics of the songs must reflect the real theme of the story. For example one day the producer of a movie asked me to give my opinion on how to take a love scene in a particular movie as I was the hero. The scene was that "I and the heroine should share the moment of love and romance". I told him that the story of the movie is not yet finalized then how can we come to a conclusion about the love scene to be taken at this premature stage. The love scene should match with that of the story, the song to be sung and the tune as well. The producer told me that he will send the recorded song so that I can come up with suggestion later. Such peculiar situation had not happened in the film Nadodi Mannan. The title song was written by Na. Muthukoothan. He is a member of the political party I belong and thereby the political ideology coincided. $\mathrm{He}$ also wrote another song "Sammathama (is it ok)". This song is a reflection of equity between husband and wife. It also contains eternal truth that if hunger arises the family should share the food among themselves as the birds do. Similarly for the other songs written by Sri.Baskaran and Kavinger Suradha, I clearly shared my views that made them to compose the songs. The song like "Thadukkathe Ennai Thadukkathe (do not stop me)" was written by Sri.Athmanadhan is a reflection of people who blindly follow certain sophistry. For example, a man who never tries to secure a job, but blames the fate for his unemployment! The super hit song - Thoongathe Thambi Thoongathe (do not sleep oh brother), written by Pattukottaiar - is not written for the children alone. It was written for people who did not care to realize the sufferings of the people but pretend to do things. Another song written by Pattukottair - Kaduvelanthenna machan (what is the use of cultivation) is the reflection of the ideology of the political party DMK. I spent good amount of time with lyric writer Sri.Lakshmanadoss to write the song "Vulaipathila Vulaippai Peruvathilla" (it is indulging in work or extracting workhappiness lies). As he is new to this field he struggled hard to complete the lyrics in accordance with my thinking. Especially, I wanted him to introduce certain new thoughts such as - happiness will not arise neither to the giver nor to the receiver. So far, the Philosophers acclaim that the giver attains happiness when he gives and sees the receiver is enjoying what is given. But I wish to propagate a message in the song that no one should be there in the country to give nor to take and everyone should have their basic necessity fulfilled without seeking it from someone else. The lyrics such as "pattathile pathavivuyarvathile" (i.e. attaining degrees and getting greater elevation in jobs) one may not attain happiness - such message is a warning message to the Ministers and the officials who are occupying higher positions in the society but doing nothing to improve the conditions of the people. 
Mr.S.M.Subbiah wonderfully composed these songs. Thus in this movie - the story, the lyrics and the tunes of the songs together reflect the message that gave impetus for its success.

The above narration establishes the fact that Dr.MGR gave importance to lyrics of the songs written for his movies. No doubt Dr.MGR engaged eminent writers to write songs according to the situation of the movies without compromising his ideologies. It is because of such an interaction with the peers Dr.MGR was able to cull out the best from them that had resulted in propagation of higher values in life through his film songs.

10. Comparative Analysis of the Twelve Songs Identified with the above Ideas That Contain the Ideas of Socialism and Communism as Propagated by Karl Marx

Let us take two songs as the necessary context from the above movie Nadodi Mannan and establish the fact that these songs contain the idea of social welfare of Karl Marx.

\section{Context-I}

Lyrics written by Shri. Pattukotai Kalyanasundaram and sung by Sri.Sirghali Govindarjan Film released in the year 1958 Directed by RR Chandran: Music: SM Subbiah:

\section{English Translation of the song:}

Tilling the land that was kept idle and ploughing the land after overcoming laziness.

Raising the level of the banks of water bodies and channelling the canals aptly to draw water to the paddy field and sowing the seed of samba rice it has now grown abundantly in such a way we could not see the boundary of the paddy field.

Just growing the paddy field like that what do we get Oh my dear husband our hands and legs alone remains.

Let the paddy fields grow now oh beloved girl a bright future is ahead of us.

Dig the earth to build quarries and get ore from the depth of the quarries to extract gold from it, constructing bungalows along with compound walls and dwelling deep in to the sea to get pearls, the sufferings undergone by these labour force who stand as a guiding force will change and I foresee that good times awaits them.

Why should hunger visit to the lives of those labour force who works like bullock?

It is due to the fact that the wealth earned by them goes to the hands of few (owners/capitalist).

What should be done to remove sufferings of this labour force?

They should think and progress beyond their mundane existence of working merely to fill their bellies.

Is it not a danger to perpetuate the routine sufferings of peasants (and thereby capitalize them not to think beyond the pale of mundane existence)?

Soon they will overcome the darkness in their mind (through knowledge) and even the slum dwellers will be happy.

I myself will enact laws with which these people will prosper in the nation.

\section{Interpretation:}

The above song reflects the sufferings undergone by the labour force who work at the paddy field, at the quarries, at the construction arena and at deep sea. This song stresses the importance of the contributions of the labour force in different fields for the growth of the country at the same time hopes that wisdom will prevail in the minds of the labour force and thereby they will think beyond the pale of their mundane existence and raise against their oppression and prosper in the society.

\section{Critical Analysis:}

Thus this song coincides with the socialistic ideas of Karl Marx in every respect right from the concept of Alienation and to the labour revolution.

\section{Context-II}

Consider another song from the same movie Nadodi Mannan Written by Shri. Lakshmanadoss and sung by Sri.Sirghali Govindarjan Film released in the year 1958 Directed by RR Chandran: Music: SM Subbiah: 
It is due to indulging in work or extracting work from the labour force one gets happiness tell me oh comrade!

Exclaim oh comrade the work force that gets ownership (of the land tilled by them) alone attains joy oh comrade.

Oh comrade-taking pride on being educated did any one attains happiness tell me oh friend. Know that true joy is attained only when the illiterates are educated.

Happiness never comes in giving alms (to the destitute) who seeks alms, however, happiness comes when everyone in the society endeavours to work and thus sharing the wealth earned equally and lives prosperously.

Happiness never comes in obtaining higher degree and getting higher posts. It is only when your motherland attains welfare (through your hard work) you get happiness oh friend.

\section{Interpretation:}

The above song categorically states that only when the labour force who tills the land is made the owners that will lead to happiness in the society. The educated in the society should work for the welfare of the society especially uplifting the poor's and narrowing the bridge between the haves and have not's so that the economy attains equanimity.

\section{Critical Analysis:}

In this song importance of labour force was given more specifically their upliftment by way of becoming the owner of the land they cultivate and they coincide the communist manifesto especially abolition of rights of inheritance and control of education.

\section{Context-III}

Consider another song from the film: En Thangai; Written by Pavender Baradhi Dasan; Music C. N. Pandurangan and sung by Sri. T. M. Soudararajan; film released on 1952 and directed by Sri. C. H. Narayanamoorthy:

Living with all the bounty with all the retinue around just as a tiger and thereby no one is equivalent.

Making people to suffer under poverty assuming this act would result in happiness - majority of the people suffer for want of food at the same time few who swindles the wealth of the country is this fair and justifiable!

How long this world live with such a state why not this world be destroyed beyond recognition when the majority suffers while working hard and yielding less and few who are employers flourish with the work extracted from the labourers.

Whatever we see are the handiwork of the labourers but they look only poverty in their life and endures only pervasive tolerance.

To remove inequality is there any step-motherly treatment that had taken place in public distribution or is it that those who live in poverty are few.

\section{Interpretation:}

This song is composed by the great poet Pavendar Bharathidasan who paints a beautiful picture of hardship faced by the labour force; at the same time a few oppressor who prosper in the society. The song calls for a socialistic pattern of society wherein everyone is equal to each other and there is no place for the labourers to suffer otherwise the society should cease to exist. Dr.MGR wonderfully adopted this song in the above movie which coincides with the story, screen play and the situation.

\section{Critical Analysis:}

Thus the sum and substance of the song is that communist and socialistic pattern of society is necessary to weed out oppression of labour force and social equality is possible only with socialism and coincides with Marx's findings on socialism especially the concept of Alienation.

\section{Context-IV}

Consider another song from the movie Thayukku Pin Tharam Written by Shri.Pattukottai Kalyanasundaram and sung by TM Soundarajan Film released in the year 1956 Directed by MA Thirumugam:

Man is eating man Oh brother and our worry is that when will this change. 
The sky pours rain and the paddy-fields yield crops

We work hard to till the land; however the grains go to the hands of the powerful.

They do not understand when we say it is wrong and therefore

Oh brother - Man is eating man and our worry is when this tendency would change.

The crop stands keeping its head down but the grass forgetting its real nature stands tall keeping its head towards the sky.

Likewise the learned and the wise tries to sit at home however unwise and ignorant ventures to go out to create problems and therefore Man is eating man

Oh brother and our worry is that when will this change

Don't become slaves to your ego and pride oh brother

Do not give assent to everything

Do not misconstrue a cat for a tiger

Do not get frighten without understanding the real thing.

\section{Interpretation:}

This song clearly establishes the fact that it is the agricultural labourers who work hard to till the land and the out-put i.e. the grain goes to the owner of the land who does nothing however earns enormous profit and that is the reason why it is denoted in the song that man is eating man. This song also advises one not to give importance to one's ego and pride that will result in sufferings and one should become wise by using one's intellect.

\section{Critical Analysis:}

This song wonderfully picturizes the idea of labour unrest and the attitude of capitalist and thus coincides with the idea of socialism propagated by Karl Marx.

\section{Context-V}

\section{Now consider another song from the movie Tholilali (1964) written by Mr.Alangudi Somu in the year 1964} sung by Mr.T.M.Soundararajan: Music: K.V.Mahadevan.

The Lord is the owner of the Universe and I am his servant.

On the lap of mother earth everyone are my friends

Labour force is one who knows how to live greatly with what they have

He lives depending on his iron-like hands.

The attention of the Labour-forces who turns stones in to fruits will turn one day that will pave the way for a society consisting of wise people.

In the voyage of life many will come and go on the earth.

There will be few who will be like a moon in the sky in that array the labourer will stood utmost.

\section{Interpretation}

In this song the greatness of the labour force has been indicated wherein mention has been made that the labour force knows how to lead a contended life in society and they will create a society of wise men and set great example on the Earth whose fame will be as the moon in the sky. The assumption that labour force leading a contended and ethical life that will lead to an egalitarian society is the sum and substance of this song.

\section{Critical Analysis}

The main contention of the song that the attention of the labour force will turn one day and that will pave way to wise society explains the fact that there will be revolution in the world against the oppressor viz., the Capitalist and their possessions will be made public. The qualities of life of labour force as indicated in the song is a reflection of Karl Marxs' labour welfare idea after the revolution. 


\section{Context-VI}

Consider another song from the film: Padakotti Written by Sri.Vali; music composed by Sri.M.S.Viswanathan \& Ramamoorti and sung by Sri.T.M.Soudararajan film released on 1964 and directed by Sri.T.Prakash Rao:

Whatever has to be given has been given but to whom it was given - is it for a single entity; no it is given for the nation God has given the wealth and the bounty.

Will the breeze refuse to invade into the doors of the house made out of mud?

Will the evening moon refuse to shed its light to the house of poor?

God never gives one to you and another to me.

No sin can be ascribed on to the creator or to those who suffer out of hunger.

It is those who had taken away the wealth and those who laboured for it stands on the streets.

God never gives so that few should live at the cost of many who had to suffer.

People exist with no means to fulfil their wants at the same time those who have bounty of wealth will exclaim that they have nothing.

They have pocket full of money but their mind is dark to part with the money for the welfare of others.

Let us praise those people who keep all the wealth into a common treasury.

\section{Interpretation}

This song discusses the plight of the poor's while the nature never distinguishes poor and rich only the upper class the wealthy alone separates themselves from others in a society and create a gap between haves and have not's thus this song not only enunciates the attitude of the haves but stresses the importance of a society whereby only equality prevails.

\section{Critical analysis}

This song touches the very basic fabric of socialism and the necessity of equality in a society and thus coincides with Marxism.

\section{Context-VII}

Consider the following song from the film Chandhrodhayam (English: Moonrise), which was a 1966 Indian Film directed by K.Shankar, starring MG.Ramachandran in the lead role, with Jayalalitha, MN Nambiar, Nagesh enacting supporting roles. Music by M.S.Viswanathan:

\section{English Translation of the Song:}

Budha Jesus and Gandhi were born on the Earth only because of poor's like us

Ganga Yamuna and Cauvery (rivers) flow because to quench the thirst of workers like us

Why should we work bending our back like a question mark?

Just to lead a life of prestige and prime

To seek a shade there is a tree

To face the careless criticism there is a companion

When darkness arise there is a lamp to lit

Similarly there is a future for everyone

Truth pervades everywhere and it is the language of God

Goodness will arrive tomorrow that should be our confidence

Those who possess money never has the tendency to part with

Wealth never goes to the person who intend to part with

Mind which is like a temple is about to be opened

God will arrive in it uninvited 
Those who cry are able laugh and those who laugh are able to cry

These are not the handy work of FATE

Those who possess wealth (abundantly) is not granted by the God

\section{Interpretation of the Song}

Lord Bhudha, Christ Jesus and Mahatma Gandhi were born on this earth only because of poor's like us (labourers). Rivers Ganga, Yamuna and Cauvery is flowing just to quench the thirst of workers. The workers bend their back to work hard only to lead a life to uphold the prestige and prime of their family. There is tree shade to take rest. To face careless criticism there is a companion. As there is a lamp to lit to weed out the darkness there will be a bright future to everyone (worker) in the world.

Truth is the language of God and it pervades everywhere. One should lead a life with the confidence in his mind that their life will be better off tomorrow. It is a be-wilderness that those who possess wealth will not have the tendency of charity to part with their money. Conversely, wealth never reaches to those who have the tendency to do charity. If we keep our mind as pure as a temple God will manifest in it un-invitedly. It is said in the Bible "Blessed are those who are pure at heart-Indeed they are children of God". It is not Fate which makes the laughing people to cry or vice-versa. God never singles out a particular person to possess wealth abundantly in the world

\section{Critical Analysis}

The above song gives a wonderful motivational song that aims to bring in confidence to the labourers who toil to lead a life of prestige and prime. Indeed such songs have become so popular and millions of people viewed them in the u-tube even these days 11,78,445 views): N.Janarthanan after viewing this song in U-tube (https://www.youtube.com/watch?v=eMIvSJ7JeAo78,445 views): exclaimed that "this song written by late Shri.Vali.Mr.Vali had a mental set of socialism. Our MGR had also been brought up from poor family, and always thinking to help the poor and downtrodden throughout his life time. This lyrics reflected their mindset and TMS gave life to this song by his voice. It is a immortal song in Tamil film song history. This song thereby largely coincides withevery sense of Marxs Ideology of socialism

\section{Context-VIII}

Consider the song sung by none other than the former Chief Minister of Tamil Nadu late Puratchi Thalaivi Madam Dr.J.Jayalalitha belovedly called AMMA (mother) in the movie Adimaipen released in the year 1965: Music Director K.V.Mahadevan, Director: K.Shankar Filmfare Award for Best Film - Tamil (she is the successor of Dr.MGR who upheld the ideologies of Dr.MGR till her last breath (05.12.2016) i.e. for more than 29 years and I dedicate this research work to the blessed feet of Puratchi Thalaivi Dr.J.Jayalalitha belovedly called “Amma” (Mother)).

Mother stands for love

Father stands for knowledge

Teacher stands for education

They are Gods in the world

Child calls Mother and Mother

Also calls the child Mother

Meaning of love an exclamation of virtue

All leads to a single word mother

She carries the baby for ten months

Forgets her suffering soon after she yields the baby

She protects the child by undergoing diets

She converts her blood in to feeding milk

The wealth given by the nature should be kept in public

That should be equally distributed to both the haves and have nots

Rain does not pour for one person 
Moon does not shine for one person

If whatever comes are distributed to all equally

There can be no strife or struggle

\section{Interpretation:}

This song advocates not only the position of different relationship in life but enunciates how knowledge flows and the duty to improve the life style of the public, finally it proposes a general welfare concept that would result in a conflictless global society an obligation rest upon the planners of the society not only to augment the skills of the masses but provide opportunity to sustain it thereby there will be no conflicts between the haves and have not's.

\section{Critical Analysis:}

This song contemplates that wealth that has been given by nature is to be kept in public and be equally distributed to both haves and have not's and thereby largely coincide with abolition of rights of inheritance of communist manifesto. Puratchi Thalaivar Bharat Ratna Dr.MGR wrote a WILL of testament of his property and wants charity from the money earned obtaining his properties and that is being done even today:

Nearly 29 years after the death of AIADMK founder and former Tamil Nadu Chief Minister M.G. Ramachandran, the Madras High Court appointed retired judge Justice D. Hariparanthaman to administer his properties, ending one more battle over the execution of the actor-politician's will. Through the WILL, which was registered on January 18, 1987, MGR had appointed senior advocate N.C. Ragavachari (since deceased) as its executor. He had named a relative M. Rajendran to succeed Ragavachari after the latter's lifetime. Since Mr. Rajendran, the last executor appointed by MGR, died on January 8, 2013, and as the WILL did not name any one to succeed him, Mr. Rajendran's wife Latha and other relatives of MGR approached the High Court seeking to appoint them as the Administrator of the properties.

Refusing to accept their applications, Justice Sundresh said, "The testator is none other than the former Chief Minister of the State, who is known to be a philanthropist par excellence. After the life time of Mr. Rajendran, the WILL authorises the High Court to appoint an Administrator as per law. Thus, conspicuously, the WILL did not name anyone thereafter including any of his relatives." Noting that the intention of MGR was very clear that the properties were to be utilised for a philanthropic purpose mainly, among other things, Justice Sundresh appointed Justice Hariparanthaman as the Administrator (Hindu News Paper FEB.19, 2017).

\section{Context-IX}

Consider another song from the movie Thanipiravi; song written by Kannadasan and sung by T. M. Soundararajan, K.V. Mahadevan film directed by M. A. Thirumurugam (1966).

Oh that hands which works hard and creates a new order in the world.

That hands which construct dams to preserve river water

That hands which weaves to produce cloth to save the dignity of men and women

That hands that sows seeds and removes the unwanted plants on the field.

Our hands forever reflects the dark red sky.

That hands which created heavy machineries

That hands that laid roads to integrate the world

All the prides in the world are products and results of our hands.

Our hands are the symbols that turned cold blood into sweat

Let all the labour force in the world assemble at one place and exclaim that we belong to one community that is the labour force.

If time comes we will wage war lifting the weapons in our hands.

Let us dance exclaiming righteousness and people's rule.

\section{Interpretation:}

This song clearly indicates the nature of duties performed by the skilled labour force right from tilling and sowing seeds, to building machinery for the factories to function and constructing roads to make movement of people and 
things from one place to other possible. All this was possible only with the dedicated work of labour force and there is no reason why they cannot become owners of the factors. If it did not happen why can't the labour force wage a war against the oppressor is the sum and substances of the song.

\section{Critical Analysis:}

This song not only enunciates the nature of works performed by the labour force and establishes a fact that without labour force infrastructural development becomes impossible. If such a thing is a fact why the labour force cannot claim ownership of the factors of production and this clearly establishes the dream of Karl Marx's of labour revolution.

\section{Context-X}

Consider another song from the film: En Annan; Written by Sri.Kannadasan; Music K. V. Mahadevan Sri.Vedha; and sung by Sri. T. M. Soudararajan film released on 1970 and directed by Sri. Pa. Neelakandan:

You have a heart and justice prevails in it therefore run Oh King and wait for the appropriate time to come.

Living in constant fear is enough now you have to flow like a stream of river.

Why should there be blood in a slave's body and why should there be house for a person who lives in constant fear.

Why should one fear on seeing injustice meted at him; what have you brought to this world exclaim fearlessly (stretching your moustache)

Building palaces (sky scraper - buildings) and very near to it we find thatched huts and you call this is a golden world - Indeed this Earth will laugh at you and the God above will also laugh at us.

Keep your feet with the firm belief that you will succeed for your success you alone will be responsible - just leave your worries.

You must raise your shoulder to find out victory or success if not do not hesitate to lift your sword.

\section{Interpretation:}

Thus in this song the inequality that is prevailing in the society is beautifully painted with an example of high rise building along with the huts nearby and thereby establish the fact of ups and downs in the society. This song gives sane advice to the masses that they should be confident of their own skills and try to achieve success following fair practise.

\section{Critical Analysis:}

Thus this song criticizes the inequality that prevails in the society and educates the labour force the confidence required to march ahead in their fight for a revolution and thus coincides with the theory of Communism.

\section{Context-XI}

Consider another song from the film: Vulagam Sutrum Valiban; Written by Composed by Sri.Vedha; lyrics written by Shri.Kannadasan and sung by Sri.Seerkhazhi Govindarajanfilm released on 1973 and directed by Puratchi Thalaivar MG Ramachandran: Music Director: M. S. Viswanathan

History will speak about the victory tomorrow.

If this force loses which force will then win.

It is the war for justice

The world will certainly appreciate and acknowledge talent that arise

A day will come when swindling by the (capitalist) will cease to exist and that day will put an end to saying no to poor's needs to equitable distribution and justice.

Then the history of those who possess power by merely deceiving others will also change.

It is the gift given by the nature to nurture and develop knowledge and skill in which destruction alone will remain to those who try to destroy goodness with a view to spoil the country.

Nurturing goodness is knowledge.

Keeping away from evil things is also knowledge 


\section{Intrepretation:}

In this song an assumption has been made to remove capitalism and bring in equitable distribution of wealth, justice as well as a chastened welfare state. This song not only enunciates the inner feelings for the sufferings undergone by the poors who were oppressed by the rich and the powerful but also contemplates the steps to be taken to weed out the sufferings and the steps to be taken to eradicate the upper hand gained by the powerful. This song also suggests the moral fabric of a society wherein respect for fellow being is given importance at the same time relying on equity and justice in the society.

\section{Critical Analysis:}

The communistic idea of labour revolution is contemplated in the song besides its talks about labour welfare as well as equitable distribution of wealth and largely coincides with the ideas contain in the communistic manifesto.

\section{Context-XII}

Consider another song from the film: Engavettu Pillai; Written by Sri.Vali; Music Viswanathan and Ramamoorthy Sri.Vedha; and sung by Sri.T.M.Soudararajan film released on 1965 and directed by Sri.Chanakkya:

If I am empowered to rule and govern the state and that happens, these poor's will not suffer.

There will be no penury till they breathe their last.

They will not dwell in the sea of fears.

Any mistake committed knowingly even if he is God of Heavens I will not let him go unpunished.

I will make them to work and earn for their living- I will not touch their belongings.

Some (politicians) to come to power to satisfy their own needs and desires will catch hold of the legs of the public indeed.

They do not care for shame and dignity.

Forever they chide with power. The day will come and I will be given the responsibility;

Then I will curb the deceitful act of these selfish and aggrandizers.

Living in accordance with equity and justice and a new path- I will be awake to see the face of the nobles.

I will not wait to witness the untold sufferings of the poor's.

There is a God and a path leads to him and I always try to uphold it.

Christ came in the past then came Mahatma Gandhi-

They came to correct the humans but they did not change.

Nor did they felt sorry for their wrong doings and forget what has told by the wise.

\section{Interpretation:}

In this song an assumption has been made that if Dr.MGR happens to rule the state of Tamil Nadu the poor's will not suffer. The poors need not fear till their lost breath. There will be no place for oppressor and everyone will be made to work for their livelihood. Unlike others who want to capture power will fall at the feet of the voters just to accumulate money and power. The sayings in the song came true and Dr.MGR became the Chief Minister of Tamil Nadu.

One of the famous welfare schemes that were introduced by him besides many other schemes oriented towards upliftment of poor's is the mid-day meals scheme called the Chief Minister's Noon Meals Scheme. It is worth ponder over the famous speech delivered by Dr.MGR on 30.06.1982 through AIR (17):

\section{In the words of Dr.MGR:}

I came here to speak about the Noon Meal Scheme which was introduced with a view to relieve the sufferings created by hunger faced by the poor children of Tamil Nadu by feeding them atleast once a day. Mahatma Gandhi used to say that "God shows his form to the poor's through the food plate" at the same time Peringer Anna used to say that I could see God in the smiling face of the poor's. The great Thiruvalluvar says in Thirukural Couplet No.734

"Devoid of starvation, disease and attack by other country should alone be considered as Nation." Great saint 
Avvaiyar says "greatest distress is poverty and that too poverty occurs in childhood days". I introduced the Mid-Day Meals Scheme as I have undergone such a state of starvation when I was a child. Had not my neighbour a generous lady gave a bowl full of rice that had appeased the hunger caused due to starvation for nearly three days - myself, my mother along with my brother would have died long ago"! Such a motherhood had made me the Chief Minister of Tamil Nadu with full of confidence in me and to wipe the tears of millions of such mother-hood, I have undertaken the path known to me. I have realized that it is my duty to reduce the sufferings of the mother-hood atleast to a certain extent and introduced this scheme so that poor children from the age of two to ten will benefit from this scheme. According to census of Tamil Nadu the total population is 4.82 crores in 1981. In which the children belonging to the age of two to five is estimated to be 42.10 lakhs. Children belonging to the age limit between 5 to 10 is 73.73 lakhs. Thereby the total children from 2 to 10 age are 105.83 lakhs in which about 60 lakh children (who belong to below poverty line) will be benefitted. For the children with the age limit from 2 to 5 will avail this benefit from the child care centres. The children beyond the age of five will avail this benefit from their own schools. The district level officers will take the responsibility of implementing the scheme. I have taken the responsibility of myself to head the higher level committee consisting of eminent persons who are ministers and philonthrophers.

The Social Welfare Department is running about 4343 child care centres throughout the state moreover this scheme facilitates establishment of one centre per village and thereby 15,501 child care centres were established. To impart education, a qualified lady teacher has been appointed in each of the centre. Preference has been given to young widows. They will be nominated by the officers in consultation with noted social personality of the local area. The selection process was over and they are undergoing training and they will take charge from $1^{\text {st }}$ July 1982 onwards. The children beyond the age of 5 to 10 will avail the benefit from thirty six thousand primary schools of Tamil Nadu. It is true that a noon meal scheme is being run by the state of Tamil Nadu for the school children but there is a big difference in the new scheme introduced by me. The old scheme benefits only one third of the pupils. The new scheme will benefit all the poor children of the schools. In the old scheme, mid-day meal was provided only for 200 days but the new scheme provides food for all the 365 days of the year. The government spends about 10 paisa in the old scheme and every block should give 5 paisa per student. However due to economic scarcity the blocks were not in a position to meet the expenditure and thereby I have ordered that the entire expenditure would be borne by the Government itself and thereby the old scheme got the recognition of the Government. This scheme should not be considered merely as a noon-meal providing program. I expect these centres will provide avenues for the poor children to come together forgetting their religion \& cast and grow in the atmosphere of total freedom from the social evils that would pave the way for social integration and general health will also be promoted. I feel the children are the wealth of the nation and it is my duty to nurture them so that the burden on their parents will be reduced. Reducing the burden of the common man is paramount importance of every government which is aiming for an integrated growth and development of an economy. Bharat Ratna Dr.MGR realised it and implemented this most useful social welfare scheme that had attracted the attention of leading politicians not only in India but also all over the world.

\section{Conclusion}

In this paper an overview of the origin of media has been discussed. The importance given to production of quality songs has also been discussed. After introducing the Hero of the research work necessary genesis on the ideas of Communism and Socialism as propounded by the Great Karl Marx has been dealt in detail. Thereafter with the use of the methodology evolved an attempt has been made to theoretically compare with the selected twelve songs. Translation, interpretation and critical analysis of each song were arrived under each context. The Critical analysis of the various intersections of the twelve songs identified by way of contexts establishes the fact that they contain the genesis of ideas of Socialism and Communism as propounded by Karl Marx. Moreover this study justifies the fact of production of songs of philosophical import unlike the rap music with emotionally degrading content that spoils the character of the listeners. The conclusion is inescapable that Dr.MGR's contribution towards inclusion of film songs that propagates the fundamental rights of the common man towards betterment of the society is a boon to the society and he was rightly awarded the highest civilian award the Bharat Ratna though of course posthumously. 


\section{References}

American Academy of Paediatrics "Policy Statement - Media Violence". Retrieved from http://pediatrics.aappublications.org/content/pediatrics/124/5/1495.full.pdf.

Bertell Ollman. (2017) What is Marxism? A Bird's-Eye View. Retrieved from https://www.nyu.edu/projects/ollman/docs/what_is_marxism.php

Harcourt Brace Jovanovich, Inc. (1964). END NOTES Karl Marx: Early Writings. New York, McGraw-Hill.

Idaya. S.J. (2016). Tamil Movies that had created an Impact" Thuklak Tamil Weekly Magazine.

Karl Marx (1964). Selected Writings in Sociology and Social Philosophy. London, McGraw-Hill.

Kumaravel. Ve. MGR Speeches and Writings by (1) (pp 323-343) published by Mullai Pathipagam Chennai 2015.

Kumaravel. Ve., MGR Speeches and Writings by (pp 96-125) published by Mullai Pathipagam Chennai 2015.

Lewis A. Coser. (1977). Masters of Sociological Thought: Ideas in Historical and Social Context (2nd Ed.). Fort Worth:

Ministry of Information Broadcasting, New Delhi, India - State Awards for Films 1955. Retrieved from http://dff.nic.in/2011/2nd_nff_1955.pdf

Muthulingam. Na. (2016). Kumudam Tamil Weekly Magazine dated 03.08.2016 PP 108 to 114.

Muthulingam. Na. (2016). Manathai Thotta Makkal Thilagam by Edited by Sabitha Joseph PP 23-45, (2014).

Ram Pande. (1985). Congress 100 Years. Jaipur Publishing House: India.

Ramakrishnan. K.P. (2007). “MGR oru Sagaptham” published by Vikadan Prasuram (pp 188).

Sarvaharana. P., P. Thyagarajan \& S. Manikandan. (2017). A Study on Ethical Values as Contained in Bharat Ratna Dr.M.G. Ramachandran's Selected Film Songs - An academic comparative analysis with contemporary theories of ethics. International Journal of Research In Commerce, Economics \& Management, 10-16.

Shrikanth Veeravalli. (2013). MGR A Biography. Rupa Publications: India Pvt. Ltd.

Steve Sullivan. (2017). Encyclopedia of Great Popular Song Recordings. Rowmand \& Littlefield Publishers: Maryland London.

The Broadway Melody. Retrieved from https://en.wikipedia.org/wiki/The_Broadway_Melody

The Great Ziegfled. Retrieved from https://en.wikipedia.org/wiki/The_Great_Ziegfeld

The Hindu, News Paper $\quad$ (1947): Retrieved fromhttp://www.thehindu.com/todays-paper/tp-features/tp-cinemaplus/rajakumari-1947/article3023314.ece

The Hindu. (2014). Retrieved fromhttp://www.thehindu.com/features/cinema/celluloid-stories/article5810184.ece

$\begin{array}{llllll}\text { The Hindu. } & \text { (2017). } & \text { Retrieved } & \text { February }\end{array}$ Fromhttp://www.thehindu.com/news/national/tamil-nadu/high-court-appoints-former-judgeto-administrate-mgr s-properties/article16696149.ece

V. L. Lenin. (1946). The Great Initiative, Prague. Engels: Manifesto of the Communist Party.

West Side Story. Retrieved fromhttps://en.wikipedia.org/wiki/West_Side_Story_(film). 